Journal of Clinical Investigation

Vol. 42, No. 9, 1963

\title{
EFFECT OF ENDOGENOUS AND EXOGENOUS CHOLESTEROL ON THE FEEDBACK CONTROL OF CHOLESTEROL SYNTHESIS *
}

\author{
By HIROSHI SAKAKIDA, $\dagger$ CAESAR C. SHEDIAC, $\ddagger$ AND MARVIN D. SIPERSTEIN § \\ (From the Department of Internal Medicine, The University of Texas Southwestern Medical \\ School, Dallas, Tex.)
}

(Submitted for publication September 11, 1962; accepted May 31, 1963)

The feeding of cholesterol has been found to result in a prompt suppression of hepatic cholesterol synthesis in all experimental animals thus far studied (1-4). Although the animal body, therefore, has available an effective negative feedback system that can minimize the effects of excessive amounts of exogenous cholesterol, it is not known to what extent this mechanism will respond to hypercholesterolemia of endogenous synthetic origin.

The present studies were designed to compare the influence of endogenous and of exogenous hypercholesterolemia upon the feedback control of cholesterol synthesis. Exogenous hypercholesterolemia was produced by feeding chickens a 1 or $2 \%$ cholesterol diet for a period of 2 days to 3 weeks. As an experimental model of an endogenous hypercholesterolemic state, use was made of chickens treated for comparable periods with stilbestrol ( $\alpha, \alpha^{\prime}$-diethylstilbenediol) at a dosage of 5 mg per day, a procedure that is known to produce marked hypercholesterolemia within 2 to 3 days (5).

The results of this study demonstrate that the cholesterol feedback system in the chicken is promptly activated by exogenous cholesterol; in contrast, however, the comparable hypercholesterolemia produced by the administration of stilbestrol does not cause a depression in cholesterol synthesis for a period of at least 10 days. Furthermore, the administration of stilbestrol will actually inhibit the feedback response to exogenous

* This study was supported by grants from the Dallas Heart Association, Texas Heart Association, and the American Heart Association.

$\dagger$ Postdoctoral Fellow, National Institute of Arthritis and Metabolic Diseases. Present address: Nutrition Laboratory, Faculty of Medicine, University of Kyoto, Kyoto, Japan.

$\ddagger$ Postdoctoral Fellow, National Institute of Arthritis and Metabolic Diseases.

$\S$ Research Career Award, National Heart Institute. cholesterol. A possible mechanism by which stilbestrol depresses the response of the cholesterol feedback system is presented.

\section{MATERIALS AND METHODS}

Experimental procedures. Roosters of the white Leghorn strain weighing between 1.4 and $2.5 \mathrm{~kg}$ were used throughout the study. Before the start of the experiment, they were maintained on commercial poultry chow. During the experimental period, the control animals were fed ad libitum Master laying mash to which was added oleic acid to yield a concentration of $10 \%$. The cholesterol-fed animals received the same diets supplemented either with 1 or $2 \%$ cholesterol. Cholesterol was added to the appropriate experimental diets by dissolving it in the warmed oleic acid and mixing the solution thoroughly with the mash. Stilbestrol-treated animals received daily $5 \mathrm{mg}$ of stilbestrol in oil ${ }^{1}$ injected intramuscularly. At the completion of the feeding period, the animals were killed by a blow in the cervical region and were promptly exsanguinated. The livers were then excised and cooled in ice-cold Krebs-Ringer buffer, $\mathrm{pH}$ 7.4. One-mm-thick slices of the livers were prepared with the aid of a McIlwain tissue slicer. Duplicate $500-\mathrm{mg}$ portions of the slices were placed in centerwell flasks containing $5 \mathrm{ml}$ of the Krebs-Ringer bicarbonate buffer. The substrate in all experiments was 10 $\mu$ moles of sodium acetate containing $1 \mu \mathrm{c}$ of sodium acetate-2- $\mathrm{C}^{\mathbf{1 4}}$. The flasks were treated with $95 \%$ oxygen and $5 \%$ carbon dioxide and incubated for 2 hours at $37^{\circ}$ $\mathrm{C}$ in a Dubnoff metabolic shaker.

Analytical methods. The isolation of cholesterol as the digitonide was carried out as described (6). In brief, at the end of the incubation period, the contents of the flasks were saponified by adding $0.5 \mathrm{ml}$ of $90 \%$ (weight/ volume) potassium hydroxide and autoclaving at $120^{\circ} \mathrm{C}$ for 1 hour. The contents of the flasks were transferred to 250-ml Erlenmeyer flasks, and after adding an equal volume of absolute ethyl alcohol, the nonsaponifiable material was extracted with petroleum ether. The petroleum ether extracts were taken to dryness under nitrogen, and the residue was dissolved in a $1: 1$ solution of acetone-alcohol. The cholesterol digitonide was prepared and washed as described by Sperry and Webb (7) and then dissolved in $2.2 \mathrm{ml}$ of methyl alcohol. A $1-\mathrm{ml}$

1 Eli Lilly and Co., Indianapolis, Ind. 
TABLE I

Influence of stilbestrol and cholesterol feeding on cholesterol synthesis-2-day study

\begin{tabular}{|c|c|c|c|c|c|c|c|c|}
\hline \multirow[b]{2}{*}{ Chicken } & \multirow[b]{2}{*}{ Treatment } & \multirow[b]{2}{*}{ Diet } & \multirow[b]{2}{*}{$\begin{array}{l}\text { Body } \\
\text { wt }\end{array}$} & \multirow[b]{2}{*}{$\begin{array}{l}\text { Liver } \\
\text { wt }\end{array}$} & \multicolumn{2}{|c|}{ Serum cholesterol } & \multicolumn{2}{|c|}{ Liver cholesterol } \\
\hline & & & & & $\begin{array}{l}\text { Begin- } \\
\text { ning of } \\
\text { study }\end{array}$ & $\begin{array}{l}\text { End of } \\
\text { study }\end{array}$ & $\begin{array}{l}\text { Concen- } \\
\text { tration }\end{array}$ & Synthesis \\
\hline & & & $k g$ & $g$ & $\mathrm{mg} / 100 \mathrm{ml}$ & $m g / 100 m l$ & $m g / 100 \mathrm{~g}$ & $\begin{array}{l}\text { Percentage } \\
\text { of added } \\
\text { acetate- } \\
2-C^{14}\end{array}$ \\
\hline $\begin{array}{l}1 \\
2\end{array}$ & $\begin{array}{l}\text { None } \\
\text { None }\end{array}$ & $\begin{array}{l}\text { Control } \\
\text { Control }\end{array}$ & $\begin{array}{l}1.6 \\
1.6\end{array}$ & $\begin{array}{l}22 \\
24\end{array}$ & $\begin{array}{l}142 \\
140\end{array}$ & $\begin{array}{l}173 \\
144\end{array}$ & $\begin{array}{l}247 \\
283\end{array}$ & $\begin{array}{l}0.31 \\
0.44\end{array}$ \\
\hline 3 & $\begin{array}{l}\text { Stilbestrol, } \\
5 \mathrm{mg} / \text { day }\end{array}$ & Control & 1.4 & 28 & 149 & 336 & 237 & 2.59 \\
\hline 4 & $\begin{array}{l}\text { Stilbestrol, } \\
5 \mathrm{mg} / \text { day }\end{array}$ & Control & 1.8 & 31 & 126 & 278 & 253 & 1.45 \\
\hline $\begin{array}{l}5 \\
6\end{array}$ & $\begin{array}{l}\text { None } \\
\text { None }\end{array}$ & $\begin{array}{l}\text { Cholesterol, } 1 \% \\
\text { Cholesterol, } 1 \%\end{array}$ & $\begin{array}{l}1.4 \\
1.4\end{array}$ & $\begin{array}{l}28 \\
31\end{array}$ & $\begin{array}{l}171 \\
143\end{array}$ & $\begin{array}{l}225 \\
155\end{array}$ & $\begin{array}{l}420 \\
377\end{array}$ & $\begin{array}{l}0.01 \\
0.03\end{array}$ \\
\hline 7 & $\begin{array}{l}\text { Stilbestrol, } \\
5 \mathrm{mg} / \text { day }\end{array}$ & Cholesterol, $1 \%$ & 1.4 & 34 & 138 & 429 & 262 & 0.19 \\
\hline
\end{tabular}

sample of the methyl alcohol solution was added to $15 \mathrm{ml}$ of a $0.6 \%$ diphenyloxazole, $0.03 \%$ bis-phenyloxazolylbenzene solution in toluene and assayed for $\mathrm{C}^{14}$ in a Packard liquid scintillation spectrometer. ${ }^{2}$ A second $1-\mathrm{ml}$ sample of the digitonide solution was used for assay of the total cholesterol content by the procedure of Sperry and Webb (7).

\section{RESULTS}

Influence of cholesterol feeding and stilbestrol administration on hepatic cholesterol synthesis. As indicated by the results presented in Tables I to IV, incorporation of cholesterol into the diet of the chicken resulted in an almost complete suppression of hepatic cholesterol synthesis, a finding which demonstrates that the cholesterol feedback system previously observed in numerous other animal species is also operative in the bird. Cholesterol synthesis was inhibited to one-tenth and one-thirtieth the control values after the first 2 days (Table I). By day 5, suppression of synthesis was maximal (Table II) and remained so throughout the period of study (Tables III and IV). The degree of inhibition of hepatic cholesterol synthesis by exogenous cholesterol is as great as that found in the rat $(2,3,8)$ in that after 5 days, a suppression to at least one one-hundredth the control value was observed in all but one of the chickens.

In contrast to the case of the cholesterol-fed rat (8), dietary cholesterol, as previously demon-

\footnotetext{
2 Packard Instrument Co., La Grange, Ill.
}

strated (9), produced a definite increase in the level of serum cholesterol of the chicken; furthermore, in general, the concentrations of liver cholesterol paralleled those of the serum and were consistently increased above the levels in the control chickens.

As first reported by Lorenz, Chaikoff, and Entenmen (5), the administration of stilbestrol resulted in a prompt elevation in serum cholesterol that was evident in the animals after 2 days of treatment (Table I). In every case, the hypercholesterolemia in this group of chickens exceeded that seen in the birds fed the $1 \%$ cholesterol diet, and after 3 weeks of treatment (Table IV) was approximately in the same range, i.e., over 1,000 mg per $100 \mathrm{ml}$, as that observed in the chickens fed cholesterol at a $2 \%$ level. Despite this marked hypercholesterolemia, at the 2- and 5-day periods (Tables I and II), the stilbestrol-treated chickens showed an elevated rate of hepatic cholesterol synthesis. In the animals treated for 10 days, cholesterol synthesis was still within the normal range (Table III), and even after 3 weeks of estrogen therapy, when the blood cholesterol levels had reached levels well in excess of $1,000 \mathrm{mg}$ per 100 $\mathrm{ml}$, the degree of suppression of cholesterol biosynthesis was much less than that found in the cholesterol-fed chicken.

It is likely that the intact livers of the stilbestroltreated chickens actually synthesized cholesterol at rates somewhat greater than are indicated by 
CHOLESTEROL FEEDBACK CONTROL

TABLE II

Influence of stilbestrol and cholesterol feeding on cholesterol synthesis-5-day study

\begin{tabular}{|c|c|c|c|c|c|c|c|c|}
\hline \multirow[b]{2}{*}{ Chicken } & \multirow[b]{2}{*}{ Treatment } & \multirow[b]{2}{*}{ Diet } & \multirow[b]{2}{*}{$\begin{array}{c}\text { Body } \\
\text { wt }\end{array}$} & \multirow[b]{2}{*}{$\begin{array}{c}\text { Liver } \\
\text { wt }\end{array}$} & \multicolumn{2}{|c|}{ Serum cholesterol } & \multicolumn{2}{|c|}{ Liver cholesterol } \\
\hline & & & & & $\begin{array}{l}\text { Begin- } \\
\text { ning of } \\
\text { study }\end{array}$ & $\begin{array}{l}\text { End of } \\
\text { study }\end{array}$ & $\begin{array}{l}\text { Concen- } \\
\text { tration }\end{array}$ & Synthesis \\
\hline & & & $k g$ & $g$ & $m g / 100 m l$ & $\mathrm{mg} / 100 \mathrm{ml}$ & $m g / 100 \mathrm{~g}$ & $\begin{array}{l}\text { Percentage } \\
\text { of added } \\
\text { acetate- } \\
2-C^{14}\end{array}$ \\
\hline 8 & None & Control & 1.8 & 39 & 112 & 129 & 345 & 1.27 \\
\hline 9 & None & Control & 1.6 & 38 & 168 & 143 & 258 & 1.68 \\
\hline 10 & $\begin{array}{l}\text { Stilbestrol, } \\
5 \mathrm{mg} / \text { day }\end{array}$ & Control & 1.6 & 48 & 169 & 583 & 263 & 5.74 \\
\hline 11 & $\begin{array}{l}\text { Stilbestrol, } \\
5 \mathrm{mg} / \mathrm{day}\end{array}$ & Control & 2.0 & 69 & 144 & 886 & 271 & 4.67 \\
\hline 12 & None & Cholesterol, $1 \%$ & 1.4 & 38 & 143 & 385 & 530 & 0.01 \\
\hline 13 & None & Cholesterol, $1 \%$ & 1.8 & 33 & 149 & 311 & 381 & 0.03 \\
\hline 14 & None & Cholesterol, $1 \%$ & 1.6 & 32 & 144 & 449 & 527 & 0.01 \\
\hline 15 & None & Cholesterol, $1 \%$ & 1.8 & 54 & 170 & 378 & 537 & 0.01 \\
\hline 16 & $\begin{array}{l}\text { Stilbestrol, } \\
5 \mathrm{mg} / \mathrm{day}\end{array}$ & Cholesterol, $1 \%$ & 1.8 & 65 & 126 & 957 & 325 & 4.04 \\
\hline 17 & $\begin{array}{l}\text { Stilbestrol, } \\
5 \mathrm{mg} / \text { day }\end{array}$ & Cholesterol, $1 \%$ & 1.6 & 59 & 175 & 1,162 & 431 & 0.73 \\
\hline 18 & $\begin{array}{l}\text { Stilbestrol, } \\
5 \mathrm{mg} / \text { day }\end{array}$ & Cholesterol, $1 \%$ & 1.6 & 55 & 135 & 705 & 334 & 4.20 \\
\hline 19 & $\begin{array}{l}\text { Stilbestrol, } \\
5 \mathrm{mg} / \mathrm{day}\end{array}$ & Cholesterol, $1 \%$ & 1.8 & 76 & 173 & 1,095 & 317 & 2.67 \\
\hline
\end{tabular}

the data given in Tables II, III, and IV, which liver weights : normal, $44 \mathrm{~g}$; stilbestrol-fed, $74 \mathrm{~g}$ ). are derived from experiments using $500 \mathrm{mg}$ of As a result, cholesterol synthesis in the intact liver liver. The livers of the chickens receiving stil- was probably increased well above normal in the bestrol for more than 2 days were definitely larger stilbestrol-treated chickens during the earlier pethan were those of the normal chickens (average riods of treatment.

TABLE III

Influence of stilbestrol and cholesterol feeding on cholesterol synthesis-10-day study

\begin{tabular}{|c|c|c|c|c|c|c|c|c|}
\hline \multirow[b]{2}{*}{ Chicken } & \multirow[b]{2}{*}{ Treatment } & \multirow[b]{2}{*}{ Diet } & \multirow[b]{2}{*}{$\begin{array}{c}\text { Body } \\
\text { wt }\end{array}$} & \multirow[b]{2}{*}{$\begin{array}{l}\text { Liver } \\
\text { wt }\end{array}$} & \multicolumn{2}{|c|}{ Serum cholesterol } & \multicolumn{2}{|c|}{ Liver cholesterol } \\
\hline & & & & & $\begin{array}{l}\text { Begin- } \\
\text { ning of } \\
\text { study }\end{array}$ & $\begin{array}{l}\text { End of } \\
\text { study }\end{array}$ & $\begin{array}{l}\text { Concen- } \\
\text { tration }\end{array}$ & Synthesis \\
\hline & & & $k g$ & $g$ & $m g / 100 m l$ & $m g / 100 m l$ & $m g / 100 \mathrm{~g}$ & $\begin{array}{l}\text { Percentage } \\
\text { of added } \\
\text { acetate- } \\
2-C^{14}\end{array}$ \\
\hline $\begin{array}{l}20 \\
21\end{array}$ & $\begin{array}{l}\text { None } \\
\text { None }\end{array}$ & $\begin{array}{l}\text { Control } \\
\text { Control }\end{array}$ & $\begin{array}{l}2.2 \\
2.0\end{array}$ & $\begin{array}{l}62 \\
43\end{array}$ & $\begin{array}{l}141 \\
174\end{array}$ & $\begin{array}{l}104 \\
118\end{array}$ & $\begin{array}{l}182 \\
241\end{array}$ & $\begin{array}{l}4.07 \\
2.61\end{array}$ \\
\hline 22 & $\begin{array}{l}\text { Stilbestrol, } \\
5 \mathrm{mg} / \text { day }\end{array}$ & Control & 2.5 & 90 & 167 & 963 & 229 & 3.37 \\
\hline 23 & $\begin{array}{l}\text { Stilbestrol, } \\
5 \mathrm{mg} / \mathrm{day}\end{array}$ & Control & 1.8 & 73 & 119 & 1,171 & 220 & 3.28 \\
\hline $\begin{array}{l}24 \\
25\end{array}$ & $\begin{array}{l}\text { None } \\
\text { None }\end{array}$ & $\begin{array}{l}\text { Cholesterol, } 1 \% \\
\text { Cholesterol, } 1 \%\end{array}$ & $\begin{array}{l}2.0 \\
1.8\end{array}$ & $\begin{array}{l}49 \\
55\end{array}$ & $\begin{array}{l}182 \\
131\end{array}$ & $\begin{array}{l}341 \\
307\end{array}$ & $\begin{array}{l}513 \\
562\end{array}$ & $\begin{array}{l}0.01 \\
0.01\end{array}$ \\
\hline 26 & $\begin{array}{l}\text { Stilbestrol, } \\
5 \mathrm{mg} / \mathrm{day}\end{array}$ & Cholesterol, $1 \%$ & 2.5 & 85 & 175 & 1,092 & 278 & 5.20 \\
\hline 27 & $\begin{array}{l}\text { Stilbestrol, } \\
5 \mathrm{mg} / \text { day }\end{array}$ & Cholesterol, $1 \%$ & 2.0 & 60 & 153 & 603 & 238 & 2.25 \\
\hline
\end{tabular}


TABLE IV

Influence of stilbestrol and cholesterol feeding on cholesterol synthesis-3-week study

\begin{tabular}{|c|c|c|c|c|c|c|c|c|}
\hline \multirow[b]{2}{*}{ Chicken } & \multirow[b]{2}{*}{ Treatment } & \multirow[b]{2}{*}{ Diet } & \multirow[b]{2}{*}{$\begin{array}{c}\text { Body } \\
\text { wt }\end{array}$} & \multirow[b]{2}{*}{$\begin{array}{l}\text { Liver } \\
\text { wt }\end{array}$} & \multicolumn{2}{|c|}{ Serum cholesterol } & \multicolumn{2}{|c|}{ Liver cholesterol } \\
\hline & & & & & $\begin{array}{l}\text { Begin- } \\
\text { ning of } \\
\text { study }\end{array}$ & $\begin{array}{l}\text { End of } \\
\text { study }\end{array}$ & $\begin{array}{l}\text { Concen- } \\
\text { tration }\end{array}$ & Synthesis \\
\hline & & & $k g$ & $g$ & $m g / 100 m l$ & $m g / 100 m l$ & $m g / 100 \mathrm{~g}$ & $\begin{array}{l}\text { Percentag } \\
\text { of added } \\
\text { acetale- } \\
2-C^{14}\end{array}$ \\
\hline $\begin{array}{l}28 \\
29\end{array}$ & $\begin{array}{l}\text { None } \\
\text { None }\end{array}$ & $\begin{array}{l}\text { Control } \\
\text { Control }\end{array}$ & $\begin{array}{l}2.0 \\
2.2\end{array}$ & $\begin{array}{l}39 \\
42\end{array}$ & $\begin{array}{l}147 \\
147\end{array}$ & $\begin{array}{l}123 \\
152\end{array}$ & $\begin{array}{l}266 \\
260\end{array}$ & $\begin{array}{l}3.50 \\
2.22\end{array}$ \\
\hline 30 & $\begin{array}{l}\text { Stilbestrol, } \\
5 \mathrm{mg} / \text { day }\end{array}$ & Control & 1.8 & 64 & 129 & 1,502 & 324 & 0.18 \\
\hline 31 & $\begin{array}{l}\text { Stilbestrol, } \\
5 \mathrm{mg} / \text { day }\end{array}$ & Control & 2.2 & 102 & 140 & 1,124 & 295 & 0.13 \\
\hline $\begin{array}{l}32 \\
33\end{array}$ & $\begin{array}{l}\text { None } \\
\text { None }\end{array}$ & $\begin{array}{l}\text { Cholesterol, } 2 \% \\
\text { Cholesterol, } 2 \%\end{array}$ & $\begin{array}{l}2.2 \\
2.2\end{array}$ & $\begin{array}{l}50 \\
89\end{array}$ & $\begin{array}{l}135 \\
154\end{array}$ & $\begin{array}{l}1,364 \\
1,707\end{array}$ & $\begin{array}{l}689 \\
638\end{array}$ & $\begin{array}{l}0.02 \\
0.02\end{array}$ \\
\hline 34 & $\begin{array}{l}\text { Stilbestrol, } \\
5 \mathrm{mg} / \text { day }\end{array}$ & Cholesterol, $2 \%$ & 1.8 & 68 & 143 & 1,490 & 555 & 0.04 \\
\hline 35 & $\begin{array}{l}\text { Stilbestrol, } \\
5 \mathrm{mg} / \text { day }\end{array}$ & Cholesterol, $2 \%$ & 1.8 & 90 & 128 & 2,222 & 557 & 0.01 \\
\hline
\end{tabular}

A likely explanation for the failure of the stilbestrol-induced hypercholesterolemia to activate the hepatic cholesterol feedback system may be found in the analyses of the cholesterol concentrations of the livers from these animals. In contrast to the case of the cholesterol-fed birds, the hepatic cholesterol concentrations in the stilbestrol-treated chickens clearly did not parallel the serum cholesterol levels, and at least during the first 10 days of treatment, the liver cholesterol concentrations were equal to or pehaps even lower than those of the normal chicken.

It can also be seen from the results obtained in the chickens which were both fed cholesterol and treated with stilbestrol that stilbestrol treatment is capable of largely overcoming the effects of dietary cholesterol on the feedback system. In fact, cholesterol synthesis in the birds fed $1 \%$ cholesterol for 2,5 , or 10 days (chickens 7,16 through 19, 23 , and 24) continued at completely normal rates when stilbestrol was also administered. In the chickens fed a $2 \%$ cholesterol diet and treated with stilbestrol for 3 weeks, this neutralizing effect of stilbestrol was no longer apparent, and cholesterol synthesis in animals 34 and 35 was definitely suppressed.

Stilbestrol was also found to cause a relative depression in the concentration of liver cholesterol in the cholesterol-fed chickens. With one excep- tion (animal 17), the cholesterol levels of the birds receiving cholesterol and stilbestrol were lower than those receiving cholesterol alone. It is noteworthy that cholesterol synthesis was the lowest in chicken 17 of any of the stilbestroltreated chickens in this experiment.

Effect of chicken serum on cholesterol synthesis in the mouse liver. The effect on cholesterol synthesis of administering chicken serum to the mouse was next studied. Neither parenteral injections of free cholesterol nor incubation of cholesterol or its esters in vitro have been shown to influence cholesterol synthesis in liver (10). We therefore felt that an attempt should be made to determine whether parenterally administered cholesterol when bound as a lipoprotein would be effective in suppressing cholesterol synthesis. The results in Table V clearly demonstrate that inhibition of cholesterol synthesis in recipient mice can be produced by serum from cholesterol-fed chickens. This inhibition was approximately proportional to the dosage of serum administered and would appear to be specific, since the injection of equal amounts of normal chicken serum had no significant effect on cholesterol synthesis.

The most noteworthy result of this portion of the study is, however, the demonstration of a striking difference between the effects of the serum obtained from the cholesterol-fed chickens 
TABLE V

Suppression of hepatic cholesterol synthesis in the mouse by intravenous injection of hypercholesterolemic chicken serum

\begin{tabular}{|c|c|c|c|c|c|c|}
\hline \multirow[b]{4}{*}{ Treatment } & \multicolumn{6}{|c|}{ Dosage of serum administered } \\
\hline & \multirow{2}{*}{\multicolumn{2}{|c|}{$\begin{array}{c}0.4 \mathrm{ml} / \text { hour } \times 3^{*} \\
\text { Liver cholesterol }\end{array}$}} & \multirow{2}{*}{\multicolumn{2}{|c|}{$\begin{array}{c}0.8 \mathrm{ml} / \text { hour } \times 3^{*} \\
\text { Liver cholesterol } \\
\end{array}$}} & \multirow{2}{*}{\multicolumn{2}{|c|}{$\frac{1.5 \mathrm{ml} / \text { hour } \times 2 \dagger}{\text { Liver cholesterol }}$}} \\
\hline & & & & & & \\
\hline & Synthesis & $\begin{array}{l}\text { Concen- } \\
\text { tration }\end{array}$ & Synthesis & $\begin{array}{l}\text { Concen- } \\
\text { tration }\end{array}$ & Synthesis & $\begin{array}{l}\text { Concen- } \\
\text { tration }\end{array}$ \\
\hline & $\begin{array}{l}\text { Percentage } \\
\text { of acetate- } \\
\quad 2-C^{14}\end{array}$ & $m g / 100 \mathrm{~g}$ & $\begin{array}{l}\text { Percentage } \\
\text { of acetate- } \\
\qquad 2-C^{14}\end{array}$ & $m g / 100 \mathrm{~g}$ & $\begin{array}{l}\text { Percentage } \\
\text { of acetate- } \\
\qquad 2-C^{14}\end{array}$ & $m g / 100 \mathrm{~g}$ \\
\hline $\begin{array}{l}\text { None } \\
\text { Serum from }\end{array}$ & 0.77 & 252 & 0.51 & 223 & 1.05 & 204 \\
\hline $\begin{array}{l}\text { Serum from normal } \\
\text { chicken; cholesterol } \\
\text { concentration, } 109 \\
\mathrm{mg} / 100 \mathrm{ml}\end{array}$ & 0.76 & 191 & 0.52 & 243 & 0.86 & 232 \\
\hline $\begin{array}{l}\text { Serum from chicken fed } \\
2 \% \text { cholesterol for } 3 \\
\text { weeks ; cholesterol con- } \\
\text { centration, } 1,160 \\
\mathrm{mg} / 100 \mathrm{ml}\end{array}$ & 0.16 & 460 & 0.02 & 420 & 0.03 & 516 \\
\hline $\begin{array}{l}\text { Serum from chicken } \\
\text { treated with stilbestrol, } \\
5 \mathrm{mg} / \text { day for } 3 \text { weeks } \\
\text { cholesterol concentra- } \\
\text { tion, } 1,114 \mathrm{mg} / 100 \mathrm{ml}\end{array}$ & 0.75 & 220 & 0.26 & 292 & 0.18 & 192 \\
\hline Stilbestrol $0.5 \mathrm{mg} \ddagger$ & & & 0.11 & 248 & & \\
\hline
\end{tabular}

* Injected in three separate doses.

$\dagger$ Infused continuously over the 2 -hour period.

$\ddagger$ Administered intramuscularly as a single dose 4 hours before sacrifice.

and that from chickens treated with stilbestrol. At the lowest dosage of cholesterol given $(13 \mathrm{mg}$ in 3 hours), the serum from the stilbestrol-treated chickens had the same negligible effect on cholesterol synthesis as did the $1.3 \mathrm{mg}$ of cholesterol infused with the normal serum.

At higher doses of serum, some inhibition of cholesterol synthesis was produced by the hypercholesterolemic serum from stilbestrol-treated chickens; however, this effect was one-sixth and one-thirteenth that observed with the hypercholesterolemic serum derived from cholesterol-fed chickens. Evidence that residual stilbestrol in the chicken serum is probably not responsible for the failure of the mouse feedback system to respond to the serum from the stilbestrol-treated chicken is provided by the fact that a large dose of stilbestrol administered directly to one mouse did not cause an increase in cholesterol synthesis (Table V).

In Table $\mathrm{V}$ are also shown the concentrations of cholesterol in the livers of the recipient mice. A consistent difference between the response to the two types of hypercholesterolemic serum is again apparent. Serum from the cholesterol-fed chicken caused approximately a doubling of the hepatic cholesterol concentration, whereas the similar amounts of cholesterol injected in the serum from the stilbestrol-treated bird produced no significant increases in liver cholesterol.

\section{DISCUSSION}

The experiments reported here clearly demonstrate that endogenous hypercholesterolemia produced by the administration of stilbestrol to chickens does not cause the prompt depression of hepatic cholesterol synthesis that consistently follows cholesterol feeding. This finding suggests the possibility that cholesterol feedback control in the liver may be more responsive to exogenous than to endogenous cholesterol, a suggestion which is supported by the observation that in at least two other states characterized by hypercholesterolemia of endogenous origin, cholesterol synthesis is apparently not inhibited. Frantz and Hinkelman (11) have shown that during the elevation of serum cholesterol produced by injecting the deter- 
gent Triton WR-1339, cholesterol synthesis is increased; and Marsh and Drabkin (12) have reported that in the first 2 days following the induction of experimental nephrosis in the rat, the resulting moderate hypercholesterolemia does not cause a decrease in hepatic cholesterol synthesis.

The failure of stilbestrol-induced hypercholesterolemia to activate the cholesterol feedback mechanism may theoretically be due to several causes. Stilbestrol might directly influence the enzyme $\beta$-hydroxy- $\beta$-methylglutaryl reductase, which we have previously demonstrated to be the site of the cholesterol feedback reaction (8, 13 ), in such a manner as to alter the response of this enzyme to excessive cholesterol levels, or alternatively, stilbestrol could prevent the accumulation of cholesterol within the hepatic cell, thereby decreasing the cholesterol concentration at the site of feedback control.

The evidence from the present study suggests that the latter of these possibilities is, in fact, the correct one. First, as indicated by the data in Tables I to IV, despite the fact that stilbestrol produced a degree of hypercholesterolemia which in many cases exceeded that induced by dietary cholesterol, at least up to day 10 of the experiment, the concentrations of cholesterol in the liver of the stilbestrol-treated birds were consistently less than the levels found in the cholesterol-fed animals. It would seem, therefore, that whereas dietary cholesterol can readily concentrate in the liver cell, the steady-state equilibrium of cholesterol in the case of the stilbestrol-treated bird must shift in favor of the blood rather than the liver. This conclusion is consistent with that of Fleischmann and Fried (14), who found that after short periods of treatment with estradiol, the total body cholesterol concentration of the chicken did not increase. Similarly, Chaikoff, Lindsay, Lorenz, and Entenman (15) have observed that serum cholesterol from stilbestrol-treated birds enters atherosclerotic plaques less readily than does that from cholesterol-fed chickens.

More direct evidence that at an enzymatic level the feedback system in the stilbestrol-treated bird is intact is provided by the fact that after several weeks of stilbestrol administration, when a rise in the liver cholesterol concentration does occur, a definite inhibition of cholesterol synthesis is observed.
Two mechanisms might be postulated to explain the slow rate of intracellular accumulation of serum cholesterol in the stilbestrol-treated birds. ${ }^{3}$ Stilbestrol might directly affect the hepatic cell to cause it to take up or retain less cholesterol, or on the other hand, the estrogen might alter the physical or chemical structure of cholesterol-lipoprotein complex so that it less readily concentrates within an otherwise normal liver cell.

These alternative possibilities were experimentally examined by determining the effect of the hypercholesterolemic chicken serum on the intact feedback system of the normal mouse. The results of these experiments (Table V) demonstrate that the hypercholesterolemic plasma from cholesterol-fed chickens is capable of activating the feedback system of the normal mouse; however, the equally hypercholesterolemic plasma of the stilbestrol-treated roosters has very much less or no effect upon hepatic cholesterol synthesis.

It is likely, therefore, that an alteration in the structure of the cholesterol-lipoprotein complex rather than an effect on the hepatic cell is responsible for the failure of the stilbestrol-induced hypercholesterolemia to inhibit cholesterol synthesis. This conclusion is supported by the results of direct measurements of cholesterol levels in the livers of the recipient mice 1 hour after completion of the infusion. Such analyses clearly demonstrate that the administered cholesterol accumulated in the liver to a lesser extent when the donor plasma was derived from the stilbestroltreated chicken than when it was obtained from the cholesterol-fed animal.

These cross-infusion experiments thus provide direct evidence that the cholesterol which accumulates in the blood of the stilbestrol-treated chicken enters the liver cell less readily, or perhaps is released more rapidly than is that cholesterol which originates from exogenous sources. The nature of the physical or chemical change in

\footnotetext{
${ }^{3} \mathrm{~A}$ third theoretical explanation for the low levels of hepatic cholesterol in the stilbestrol-treated chicken is that hepatic destruction of cholesterol is increased by the stilbestrol treatment; however, this mechanism could obviously not account for the marked hypercholesterolemia that is induced by stilbestrol treatment. Furthermore, it is unlikely that accelerated destruction could account for the disposal of the large load of cholesterol injected during the acute cross-infusion studies in the mice.
} 
the cholesterol-lipoprotein complex which is presumably responsible for this altered intracellular accumulation of cholesterol remains to be defined.

The results reported here may also shed light on the mechanism by which stilbestrol causes hypercholesterolemia in the chicken. Both the studies of Hotta and Chaikoff (16) on the hepatic origin of plasma cholesterol and the demonstration by Ranney and Chaikoff (17) that in the absence of a functioning liver, stilbestrol will not induce hyperlipemia, indicate that the liver is the source of the increased quantities of cholesterol found in the stilbestrol-treated chicken. We would suggest, therefore, that the mechanism by which stilbestrol produces hypercholesterolemia involves a sequestration of synthesized cholesterol in the plasma. The resulting failure of the cholesterol feedback system would lead to an increase in total hepatic cholesterol synthesis and ultimately to increasingly severe hypercholesterolemia.

Although the results of the present study suggest that the cholesterol feedback mechanism may be relatively less responsive to endogenous than to exogenous cholesterol, it is also clear from the results observed in the animals given both cholesterol and stilbestrol that under some conditions even exogenous cholesterol can become incapable of activating the feedback system. It is known that elevated blood cholesterol levels in man are not lowered significantly by eliminating cholesterol from the diet, and it is evident that the circulating cholesterol under such conditions must be entirely of endogenous origin. If, as suggested, the hepatic feedback system responds relatively poorly to synthetic cholesterol, a possible mechanism for the development of human hypercholesterolemic states may involve a derangement of the lipoprotein transport of endogenous cholesterol, which prevents adequate feedback response to the elevated serum cholesterol levels.

Further examination of the factors that influence the sensitivity of the cholesterol feedback system in man, as well as in animals, is currently being carried out.

\section{SUMMARY}

1. The response of the cholesterol feedlback system to hypercholesterolemia of exogenous and of endogenous origins has been compared in the male chicken. Cholesterol feeding promptly inhibits cholesterol synthesis in the rooster, but stilbestrol treatment, despite the production of marked endogenous hypercholesterolemia, leads to normal or increased cholesterol synthesis for at least the first 10 days of treatment. These results suggest that the cholesterol feedback system may be more sensitive to exogenous than to endogenous cholesterol.

2. The concentrations of cholesterol in the livers of the stilbestrol-treated chickens were found to be much lower than were those of the cholesterolfed animals. Furthermore, the infusion of serum from cholesterol-fed chickens into mice caused an elevation of cholesterol levels in the livers of the mice, and cholesterol synthesis in these livers was significantly depressed. On the other hand, injection of serum from stilbestrol-treated chickens failed to cause an increase in the concentration of liver cholesterol in mice, and had relatively little effect on cholesterol synthesis.

3. It is concluded that stilbestrol administration influences the physical or chemical structure of the plasma cholesterol-lipoprotein complex in a manner that prevents the concentration of cholesterol in the liver cell. The resulting failure of feedback control leads to increased synthesis of cholesterol which, in addition to the sequestration of the cholesterol in the blood, is responsible for stilbestrol-induced hypercholesterolemia.

\section{REFERENCES}

1. Gould, R. G. Lipid metabolism and atherosclerosis. Amer. J. Med. 1951, 11, 209.

2. Tomkins, G. M., H. Sheppard, and I. L. Chaikoff. Cholesterol synthesis by liver. III. Its regulation by ingested cholesterol. J. biol. Chem. 1953, 201, 137.

3. Franz, I. D., Jr., H. S. Schneider, and B. T. Hinkelman. Suppression of hepatic cholesterol synthesis in the rat by cholesterol feeding. J. biol. Chem. 1954, 206, 465.

4. Beher, W. T., G. D. Baker, W. L. Anthony, and M. E. Beher. The feedback control of cholesterol biosynthesis. The Henry Ford Hosp. Bull. 1961, 9, 201.

5. Lorenz, F. W., I. L. Chaikoff, and C. Entenmen. The endocrine control of lipid metabolism in the bird. II. The effects of estrin on the blood lipids of the immature domestic fowl. J. biol. Chem. $1938,126,763$. 
6. Siperstein, M. D., and V. M. Fagan. Studies on the relationship between glucose oxidation and intermediary metabolism. I. The influence of glycolysis on the synthesis of cholesterol and fatty acid in normal liver. J. clin. Invest. 1958, 37, 1185.

7. Sperry, W. M., and M. A. Webb. A revision of the the Schoenheimer-Sperry method for cholesterol determination. J. biol. Chem. 1950, 187, 97.

8. Siperstein, M. D., and M. J. Guest. Studies on the site of the feedback control of cholesterol synthesis. J. clin. Invest. 1960, 39, 642.

9. Horlick, L., and L. N. Katz. The relationship of atheromatosis development in the chicken to the amount of cholesterol added to the diet. Amer. Heart J. 1949, 38, 336.

10. Siperstein, M. D. The homeostatic control of cholesterol synthesis in liver. Amer. J. clin. Nutr. $1960,8,645$.

11. Frantz, I. D., Jr., and B. T. Hinkelman. Acceleration of hepatic cholesterol synthesis by Triton WR1339. J. exp. Med. 1955, 101, 225.
12. Marsh, J. B., and D. L. Drabkin. Metabolic channeling in experimental nephosis. V. Lipide metabolism in the early stages of the disease. J. biol. Chem. 1958, 230, 1083.

13. Siperstein, M. D., and V. M. Fagan. Inhibition of mevalonate synthesis by dietary cholesterol. Fed. Proc. 1962, 21, 300.

14. Fleischmann, W., and I. A. Fried. Studies on the mechanism of the hypercholesterolemia and hypercalcemia induced by estrogen in immature chicks. Endocrinology 1945, 36, 406.

15. Chaikoff, I. L., S. Lindsay, F. W. Lorenz, and C. Entenman. Production of atheromatosis in the aorta of the bird by the administration of diethylstilbestrol. J. exp. Med. 1948, 88, 373.

16. Hotta, S., and I. L. Chaikoff. The role of the liver in the turnover of plasma cholesterol. Arch. Biochem. 1955, 56, 28.

17. Ranney, R. E., and I. L. Chaikoff. Effect of functional hepatectomy upon estrogen-induced lipemia in the fowl. Amer. J. Physiol. 1951, 165, 600. 